\title{
Sex and Age Morphometric Variations in Bony Nasolacrimal Duct and Fossa for Lacrimal Gland in Mexican Population
}

\author{
Variaciones Morfométricas de Sexo y Edad en el Conducto Nasolagrimal Óseo \\ y la Fosa de la Glándula Lagrimal en la Población Mexicana
}

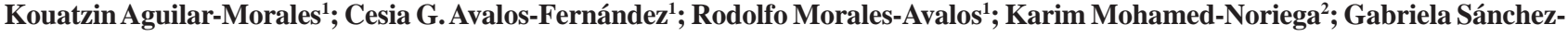
Mejorada $^{3}$; David. A. Martínez-Fernández ${ }^{1}$; Jibran Mohamed-Noriega² ${ }^{2}$ Roberto A. Lugo-Guillen${ }^{1}$; Arnulfo Villanueva-Olivo ${ }^{4}$; Edgar. E. Cuervo-Lozano²; Jesús Mohamed-Hamsho²; Rodrigo E. Elizondo-Omaña ${ }^{1}$ \& Santos Guzmán-López ${ }^{1}$
\end{abstract}

AGUILAR-MORALES, K.; AVALOS-FERNÁNDEZ, C. G.; MORALES-AVALOS, R.; MOHAMED-NORIEGA, K.; SÁNCHEZMEJORADA, G; MARTÍNEZ-FERNÁNDEZ, D. A.; MOHAMED-NORIEGA, J.; LUGO-GUILLEN, R. A.; VILLANUEVA-OLIVO, A.; CUERVO-LOZANO, E. E.; MOHAMED-HAMSHO, J.; ELIZONDO-OMAÑA, R. E. \& GUZMÁN-LÓPEZ, S. Sex and age morphometric variations in bony nasolacrimal duct and fossa for lacrimal gland in Mexican population. Int. J. Morphol., 36(2):635-641, 2018.

SUMMARY: Primary acquired nasolacrimal duct obstruction is greater in women over 40 years and has been associated with morphometric variations in the osseous nasolacrimal duct, which varies according to age and sex. The objective is to determine variations regarding sex and age of the nasolacrimal duct and osseous fossa for lacrimal gland. One hundred sixteen dry orbits from Mexican population were analyzed; subdivided into four groups based on age and sex. The length, transverse and anteroposterior diameters of the bone entrance of the nasolacrimal duct, and the length and width of the fossa for lacrimal gland were determined. Statistical tests were applied to determine the significance of the differences found between groups. The nasolacrimal duct in women had shorter length than men in both age groups. The entrance had a wider transverse diameter in women than men independently of age and its anteroposterior diameter was shorter in men under 40 years than over 40 years. The fossa for lacrimal gland was larger in women under 40 years than in men of same age group and women over 40 years old. The lower third of the was wider in women under 40 years than in women over 40 years. Our study confirms significant differences between sex and age groups in some of the morphometric measurements of bony nasolacrimal duct and fossa for lacrimal gland in Mexican population. Comparative studies with and without clinical illness are needed to clarify if the bony characteristics of those structures participate in the etiopathogenesis and distribution differences observed in sex, age and ethnicity of thisillness.

KEY WORDS: Nasolacrimal duct; Fossa for lacrimal gland; Morphometry; Primary acquired nasolacrimal duct obstruction.

\section{INTRODUCTION}

Lower lacrimal pathway obstruction in adults is a common ophthalmological problem. It has been difficult to determine its incidence in general population but it is estimated that approximately 20.2 per 100,000 of the population have symptoms of lacrimal system obstruction. It is important to consider that this percentage increases with intrinsic and extrinsic factors of the patient (Woog, 2007). Lower lacrimal pathway obstruction in adults is classified as primary when it is idiopathic and the secondary when it is caused by trauma, chronic inflammation, neoplasias, systemic diseases, infections, skin burns, drugs for glauco- ma or chemotherapeutic (Bartley, 1992). In both cases, patients may present epiphora and dacryocystitis. The greatest incidence of primary acquired nasolacrimal duct obstruction (PANDO) is in women (50-83\%) greater than 50 years of age (Woog). PANDO and to a lesser degree secondary obstruction, have been associated with variations of morphometric characteristics of the fossa for lacrimal gland (LF) and the bony entrance to the NLD, which are determined by the patient's age, gender, and race (Groessl et al., 1997; Janssen et al., 2001; Shigeta et al., 2007; Takahashi et al., 2011, 2013).

\footnotetext{
${ }^{1}$ Universidad Autónoma de Nuevo León (UANL), Departamento de Anatomía Humana Facultad de Medicina y Hospital Universitario "Dr. José Eleuterio González", Monterrey, Nuevo León, México.

${ }^{2}$ Universidad Autónoma de Nuevo León (UANL), Departamento de Oftalmología, Facultad de Medicina y Hospital Universitario "Dr. José Eleuterio González". Monterrey, Nuevo León, México.

${ }^{3}$ Universidad Nacional Autónoma de México (UNAM), Laboratorio de Antropología Física, Departamento de Anatomía, Facultad de Medicina, Ciudad de México, México.

${ }^{4}$ Universidad Autónoma de Nuevo León (UANL), Departamento de Histología, Facultad de Medicina y Hospital Universitario “Dr. José Eleuterio González”, Monterrey, Nuevo León, México.
} 
AGUILAR-MORALES, K.; AVALOS-FERNÁNDEZ, C. G.; MORALES-AVALOS, R.; MOHAMED-NORIEGA, K.; SÁNCHEZ-MEJORADA, G; MARTÍNEZ-FERNÁNDEZ, D. A.; MOHAMEDNORIEGA, J.; LUGO-GUILLEN, R. A.; VILLANUEVA-OLIVO, A.; CUERVO-LOZANO, E. E.; MOHAMED-HAMSHO, J.; ELIZONDO-OMAÑA, R. E. \& GUZMÁN-LÓPEZ, S. Sex and age morphometric variations in bony nasolacrimal duct and fossa for lacrimal gland in Mexican population. Int. J. Morphol., 36(2):635-641, 2018.

Variations in the diameter of the NLD have been studied in bone specimens and by computerized tomography (CT) (Saxena, 1984; Groessl et al.; Janssen et al.; Shigeta et al.; McCormick \& Sloan, 2009; Fasina \& Ogbole, 2013; Ramey et al., 2013; Takahashi et al., 2011, 2013; Yong et al., 2014) Obstruction of the NLD can occur anywhere in its trajectory; however, previous studies with dacryocystography and dacryoendoscopy have determined that in two thirds of patients, the most common site of obstruction is the entrance to its bony portion (62-73\%), and this is not always considered in CT studies (Sasaki et al., 2005; Francisco et al., 2007). The morphology of the entrance to the NLD varies among individuals. Determination of the diameters of the NLD by direct measure in bone specimens represents a reliable way to obtain measures of the NLD and to determine possible differences with regard to sex and age of the individuals (Takahashi et al., 2011).

Surgical treatment of NLD obstruction is performed with open or endoscopic dacryocystorhinostomy (DCR). In the DCR it is created a direct communication between the lacrimal sac in the nasal cavity through surgical osteotomy in the LF in the upper third of the NLD (Welham \& Wulc, 1987). Studies that analyze the morphometric variations of the LF and the NLD with regard to sex, age, and race could possibly explain the greater prevalence of lower lacrimal pathway obstruction in women $>50$ years. Knowledge of the morphometric variations of the NLD and the LF in different age groups and sexes will allow better planning and technique in surgical processes and would be useful in decision-making during these processes. 17-19 Therefore, the aim of this study is to analyze the morphometric characteristics of the NLD and the LF with regard to sex and age.

\section{MATERIAL AND METHOD}

The protocol was previously approved by the Ethics and Research Committees of the School of Medicine of the Universidad Autónoma de Nuevo León (U.A.N.L.) with registration number AH14-004. There were no financial or commercial interests in the performance of this study; therefore, the authors declare that they have no conflicts of interest.

This was an anatomical observational cross-sectional comparative study. The sample consisted of 116 orbits from a contemporaneous Mexican population of known sex and age (58 women and 58 men) with an age range of 18 to 99 years from a collection of bone specimens belonging to the Physical Anthropology Laboratory of the Human Anatomy
Department of the School of Medicine of the Universidad Nacional Autónoma de México (U.N.A.M). Specimens with structural anomalies or evident abnormalities of facial or cranial architecture were excluded.

To carry out morphometric measures and the statistical analysis, a primary division of the bone specimens into groups according to gender that was then subdivided into two subgroups according to age was performed. This resulted in four study groups: women less than 40 years of age (26 orbits), women greater than 40 years of age (32 orbits), men less than 40 years of age (26 orbits) and men greater than 40 years of age (32 orbits).

Morphometric measures were performed bilaterally using a millimetric digital Vernier with a precision of 0.01 mm (Mitutoyo w/Absolute Encoders Series 500), an ophthalmologic caliper with a precision of $0.25 \mathrm{~mm}$ and a flexible cable (Fig. 1a-1f).

Operative definitions of the anatomical sites used. Transverse diameter of the NLD aperture: Distance between the medial and lateral margin of the NLD aperture (Fig. 1b). Anteroposterior diameter of the NLD aperture: Distance between the anterior and posterior margin of the NLD aperture (Fig. 1c). Length of the NLD: distance between the upper aperture of the NLD in the lower margin of the inferior turbinate (Fig. 1e). Length of the LF: Distance between the upper and lower margin of the LF (Fig. 1g). Widths of the LF in its upper, middle, and lower third: Distance between the anterior lacrimal crest and the posterior lacrimal crest in the upper, middle, and lower third of the LF (Fig. 1h).

Measuring techniques. Morphometric measures of the transverse and the anteroposterior diameters of the bony aperture of the NLD and the length of the NLD were evaluated. Measures were carried out indirectly by introducing the ophthalmologic caliper in the bony aperture of the NLD; afterwards, the external diameter of the aperture of the ophthalmologic caliper was measured with a millimetric digital Vernier (Fig. 1a, 1b, 1c y 1d). The length of the NLD was determined indirectly according to the method described by Post. (Post, 1969) This consists of introducing into the NLD a known length of flexible cable that has a 2-millimeter right angle at its end it is fixed to the lower margin of the inferior turbinate (Fig. 1e). The point at which the cable reaches the bone aperture of the NLD was marked, delimiting the portion of the cable that is above the bony entrance of the NLD; the cable was then extracted and using the millimeter digital Vernier, the distance between this point and the free end of the cable was measured (Fig. 1f) This measure is subtracted from the total length of the cable; the distance obtained represents the length of the NLD. 
AGUILAR-MORALES, K.; AVALOS-FERNÁNDEZ, C. G.; MORALES-AVALOS, R.; MOHAMED-NORIEGA, K.; SÁNCHEZ-MEJORADA, G; MARTÍNEZ-FERNÁNDEZ, D. A.; MOHAMEDNORIEGA, J.; LUGO-GUILLEN, R. A.; VILLANUEVA-OLIVO, A.; CUERVO-LOZANO, E. E.; MOHAMED-HAMSHO, J.; ELIZONDO-OMAÑA, R. E. \& GUZMÁN-LÓPEZ, S. Sex and age morphometric variations in bony nasolacrimal duct and fossa for lacrimal gland in Mexican population. Int. J. Morphol., 36(2):635-641, 2018.

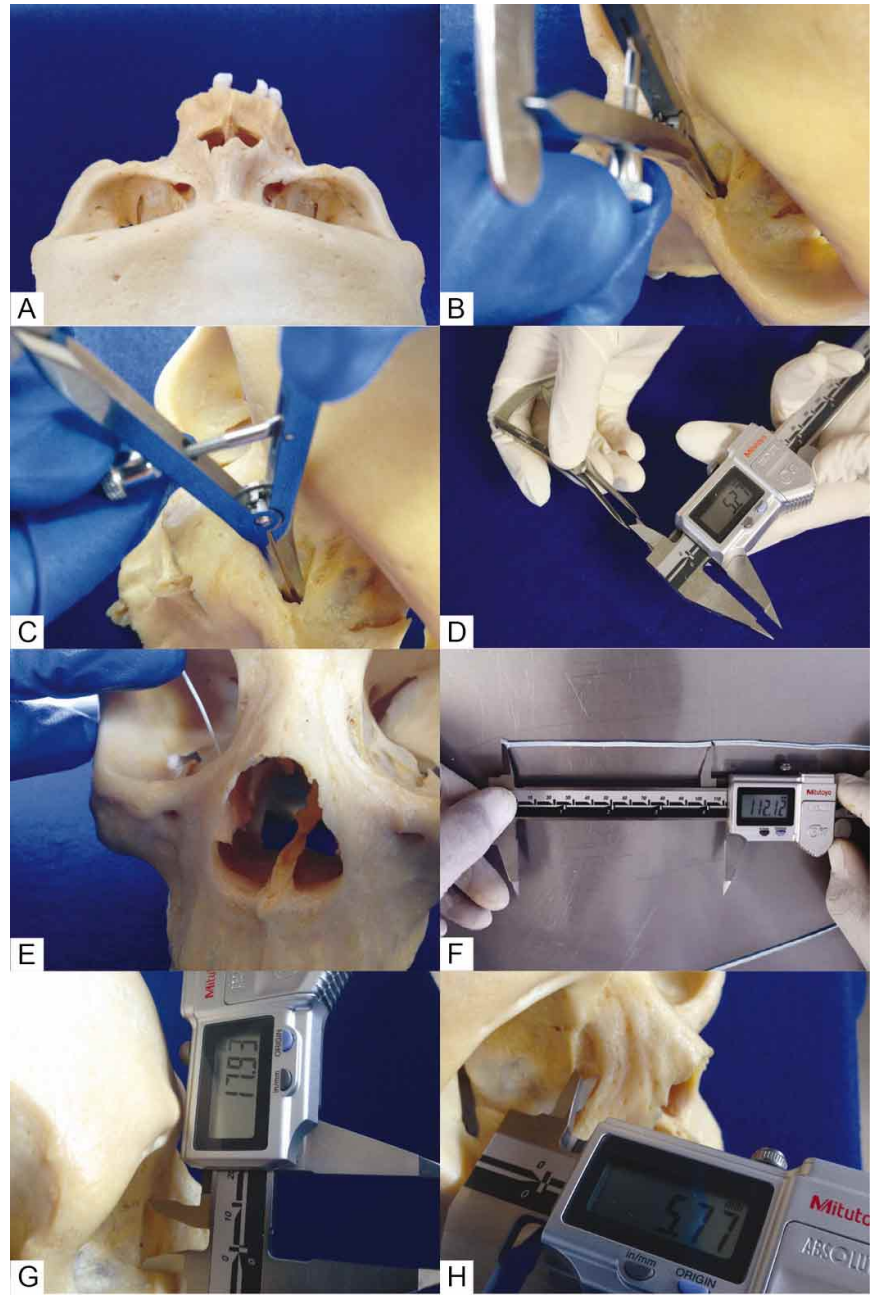

Fig. 1. Measurement technique of the different morphometric parameters in this study. a. Superior view of the (nasolacrimal duct) NLD; b. transverse diameter of the NLD bone entrance; c. Anteroposterior diameter of the NLD bone entrance; $d$. Technique of indirect measurement of the transverse and anteroposterior diameters of the NLD; e. Length of the LND. f. Indirect measurement technique of NLD length; g. Fossa for lacrimal gland length. h. Width of fossa for lacrimal gland.

The length and width of the upper, middle, and lower third of the LF were measured. Morphometry of the LF was performed directly on the bone specimens using the millimetric digital Vernier.

Statistical analysis. Was performed using SPSS version 18.0 for Windows XP. The mean and standard deviation for each parameter measured in the four groups were independently determined. A two-tailed Student's t-test was used to determine the significance of the differences in each morphometric parameter measured between men and women. In the same way, a two-tailed Student's t-test was used to compare the results of each parameter measured for the different age groups of the same sex, interpreting a $\mathrm{p}$ value $\leq 0.05$ as significant. The results are presented in Tables I and II.

Before starting the study, a random subsample of 40 orbits of random bone specimens was used to standardize the measuring technique and to perform intraobserver variation. The same observer made two measurements and a two-tailed Student's t-test was applied to determine the significance in the variations between the two measures.

\section{RESULTS}

A total of 116 orbits belonging to crania of Mexican origin, 58 males ( $32<40$ years and $24>40$ years) and 58 females ( $26<40$ years and $32>40$ years) were analyzed. The mean age was $54 \pm 23.2(18-99)$ years; In men $59.36 \pm 22.44$ (18-97) years and women were 62.16 \pm 29.64 (18-99) years; In men and women under 40 was $31.16 \pm 8.64(18-40)$ and $32.11 \pm 7.47(18-40)$ years respectively; In men and women over 40 years of age were $61.87 \pm 16.78$ (41-97) and $62.45 \pm 18.65$ (41-99) years respectively; In the $<40$ group it was $32 \pm 6.3$ years and in the group $>40$ it was $61 \pm 8.9$ years. The differences in morphometric characteristics of the NLD and the LF between gender and age are shown in Tables I and II.

Intraobserver variation. No significant differences were found between the mean morphometry results and the two measurements performed in the subsample formed by 40 orbits ( $p$ values between 0.74 and 0.96 ) for any of the parameters evaluated.

Nasolacrimal duct. The transverse diameter of the NLD bone entrance was significantly smaller in men than in women independently of the age $(p=0.045)$, we found that this difference was due to the group of men over 40 years, where they showed smaller diameter than women of the same age group $(p=0.04)$, unlike the group of men under 40 years, where men and women had a similar diameter $(p>0.05)$. Men older than 40 years had also smaller diameter than those younger than 40 years $(\mathrm{p}=$ 0.01 ). The anteroposterior diameter of the bone entrance of the NLD was significantly smaller in men under 40 years than in men over 40 years $(\mathrm{p}=0.03)$. The NLD length was significantly shorter in women than men in both age groups ( $\mathrm{p} \leq 0.05)$, but there was no significant difference between the age groups in both genders $(p>$ 0.05) (Tables I and II). 
AGUILAR-MORALES, K.; AVALOS-FERNÁNDEZ, C. G.; MORALES-AVALOS, R.; MOHAMED-NORIEGA, K.; SÁNCHEZ-MEJORADA, G; MARTÍNEZ-FERNÁNDEZ, D. A.; MOHAMEDNORIEGA, J.; LUGO-GUILLEN, R. A.; VILLANUEVA-OLIVO, A.; CUERVO-LOZANO, E. E.; MOHAMED-HAMSHO, J.; ELIZONDO-OMAÑA, R. E. \& GUZMÁN-LÓPEZ, S. SeX and age morphometric variations in bony nasolacrimal duct and fossa for lacrimal gland in Mexican population. Int. J. Morphol., 36(2):635-641, 2018.

Fossa for lacrimal gland. The length of the LF was significantly longer in women under 40 years than men under 40 years $(\mathrm{p}=0.01)$ and than women over 40 years $(\mathrm{p} \leq 0.01)$. It was similar between men and women over 40 years $(\mathrm{p}=$
$0.79)$ and between men $(\mathrm{p}=0.14)$. The width of the LF in the lower third was shorter in women over than 40 years of age than in those under than 40 years $(\mathrm{p}=0.04)$ (Tables I and II), with no significant difference in other measurements.

Table I. Differences between sex in the morphometry of the nasolacrimal duct (NLD) and fossa for lacrimal gland (LF) separated by age group.

\begin{tabular}{|c|c|c|c|c|c|}
\hline & Parameter & Age & $\begin{array}{c}\text { Female } \\
<40 a: n=26 \\
>40 a: n=32\end{array}$ & $\begin{array}{c}\text { Male } \\
<40 \mathrm{a}: \mathrm{n}=32 \\
>40 \mathrm{a}: \mathrm{n}=24)\end{array}$ & $p$ value \\
\hline \multirow{8}{*}{ NLD } & \multirow{3}{*}{ Transverse diameter } & All & $2.97 \pm 0.74$ & $2.72 \pm 0.56$ & $0.045 *$ \\
\hline & & $<40$ & $3.03 \pm 0.58$ & $2.89 \pm 0.54$ & 0.34 \\
\hline & & $>40$ & $2.92 \pm 0.85$ & $2.50 \pm 0.49$ & $0.04 *$ \\
\hline & \multirow{3}{*}{ Anteroposterior diameter } & All & $3.71 \pm 0.84$ & $3.55 \pm 0.74$ & 0.289 \\
\hline & & $<40$ & $3.65 \pm 0.85$ & $3.36 \pm 0.58$ & 0.13 \\
\hline & & $>40$ & $3.72 \pm 0.86$ & $3.80 \pm 0.87$ & 0.74 \\
\hline & \multirow{2}{*}{ Length } & $<40$ & $10.81 \pm 2.79$ & $11.87 \pm 1.09$ & $0.05 *$ \\
\hline & & $>40$ & $9.98 \pm 2.22$ & $11.87 \pm 3.08$ & $0.01 *$ \\
\hline \multirow{8}{*}{ LF } & \multirow{2}{*}{ Length } & $<40$ & $18.22 \pm 1.59$ & $16.95 \pm 1.81$ & $0.01 *$ \\
\hline & & $>40$ & $16.13 \pm 1.30$ & $16.23 \pm 1.68$ & 0.79 \\
\hline & \multirow{2}{*}{ Width upper third } & $<40$ & $5.21 \pm 0.90$ & $5.43 \pm 1.06$ & 0.41 \\
\hline & & $>40$ & $5.26 \pm 0.89$ & $5.17 \pm 0.62$ & 0.67 \\
\hline & \multirow{2}{*}{ Width middle third } & $<40$ & $6.40 \pm 0.86$ & $6.68 \pm 0.72$ & 0.18 \\
\hline & & $>40$ & $6.38 \pm 1.15$ & $6.46 \pm 0.77$ & 0.77 \\
\hline & \multirow{2}{*}{ Width lower third } & $<40$ & $5.67 \pm 0.82$ & $5.56 \pm 0.79$ & 0.59 \\
\hline & & $>40$ & $5.15 \pm 1.07$ & $5.37 \pm 0.66$ & 0.37 \\
\hline
\end{tabular}

Table II. Differences between age groups in the morphometry of the nasolacrimal duct (NLD) and fossa for lacrimal gland (LF) separated by sex.

\begin{tabular}{|c|c|c|c|c|c|}
\hline \multicolumn{6}{|c|}{$>40 a$} \\
\hline \multirow{2}{*}{\multicolumn{2}{|c|}{ Parameter }} & Sex & $F: n=26$ & $F: n=32$ & p value \\
\hline & & & $M: n=32$ & $M: n=24$ & \\
\hline \multirow{6}{*}{ NLD } & \multirow{2}{*}{ Transverse diameter } & Female & $3.03 \pm 0.58$ & $2.92 \pm 0.85$ & 0.57 \\
\hline & & Male & $2.89 \pm 0.54$ & $2.50 \pm 0.49$ & $0.01 *$ \\
\hline & \multirow{2}{*}{ Anteroposterior diameter } & Female & $3.65 \pm 0.85$ & $3.72 \pm 0.86$ & 0.78 \\
\hline & & Male & $3.36 \pm 0.58$ & $3.80 \pm 0.87$ & $0.03 *$ \\
\hline & \multirow{2}{*}{ Length } & Female & $10.81 \pm 2.79$ & $9.98 \pm 2.22$ & 0.22 \\
\hline & & Male & $11.87 \pm 1.09$ & $11.87 \pm 3.08$ & 0.99 \\
\hline \multirow{8}{*}{ LF } & \multirow{2}{*}{ Length } & Female & $18.22 \pm 1.59$ & $16.13 \pm 1.30$ & $<0.01 *$ \\
\hline & & Male & $16.95 \pm 1.81$ & $16.23 \pm 1.68$ & 0.14 \\
\hline & \multirow{2}{*}{ Width upper third } & Female & $5.21 \pm 0.90$ & $5.26 \pm 0.89$ & 0.85 \\
\hline & & Male & $5.43 \pm 1.06$ & $5.17 \pm 0.62$ & 0.28 \\
\hline & \multirow{2}{*}{ Width middle third } & Female & $6.40 \pm 0.86$ & $6.38 \pm 1.15$ & 0.94 \\
\hline & & Male & $6.68 \pm 0.72$ & $6.46 \pm 0.77$ & 0.27 \\
\hline & \multirow{2}{*}{ Width lower third } & Female & $5.67 \pm 0.82$ & $5.15 \pm 1.07$ & $0.05 *$ \\
\hline & & Male & $5.56 \pm 0.79$ & $5.37 \pm 0.66$ & 0.37 \\
\hline
\end{tabular}

\section{DISCUSSION}

In this study, we documented the morphometry bone dimensions of the NLD and the LF in relation to age and sex differences. The length of the NLD was smaller in women than men in both age groups. The NLD transverse diameter was shorter in men than in women independently of the age. The length of the LF was longer in women younger than 40 years of age than men and women older than 40 years. The width of the lower third of the LF was shorter in women 
AGUILAR-MORALES, K.; AVALOS-FERNÁNDEZ, C. G.; MORALES-AVALOS, R.; MOHAMED-NORIEGA, K.; SÁNCHEZ-MEJORADA, G; MARTÍNEZ-FERNÁNDEZ, D. A.; MOHAMEDNORIEGA, J.; LUGO-GUILLEN, R. A.; VILLANUEVA-OLIVO, A.; CUERVO-LOZANO, E. E.; MOHAMED-HAMSHO, J.; ELIZONDO-OMAÑA, R. E. \& GUZMÁN-LÓPEZ, S. Sex and age morphometric variations in bony nasolacrimal duct and fossa for lacrimal gland in Mexican population. Int. J. Morphol., 36(2):635-641, 2018.

over than 40 years of age than in those under than 40 years. The other measurements did not show significant differences between sex or age group.

Primary obstruction of the NLD is more frequent between 61 and 80 years of age (Francisco et al.). There are other factors in addition to the bony dimensions of the NLD that predispose to lower lacrimal pathway obstruction in this population, such as fibrous changes in the NLD mucosa associated with idiopathic inflammatory processes and menopausal hormone imbalances, which predispose to the accumulation of debris, the stagnation of tears and adhesion of the mucosa (Shigeta et al.).

Several authors show length differences of the bone entrance of the NLD that might be related to ethnic or methodological differences (Table III). Many of the measures performed by CT show inconsistencies and can be affected by the distance between sections, rotation, and inclination of the patient's head at the moment the study, and the morphology of the NLD itself. Furthermore, some studies do not analyze the age and gender of patients (Saxena; Groessl et al.; Janssen et al.; Shigeta et al.; McCormick \& Sloan; Fasina \& Ogbole; Ramey et al.; Takahashi et al., 2011, 2013; Yong et al.).

The measurements of the NLD bone in our study are smaller than reported in the literature in several populations, such as Asians and Africans (Saxena; Janssen et al.; Shigeta et al.; McCormick \& Sloan; Fasina \& Ogbole; Takahashi et al., 2011, 2013; Yong et al.) that showed greater diameters than those found in our population (Table III). Our study in Mexican population reports values that tend to be smaller than those of other populations, so we believe that there are differences in the NLD between ethnic groups (Table III), which could explain differences between countries in prevalence of lower nasolacrimal duct obstruction in adults.

The transverse diameter of the NLD bone entrance was significantly smaller in men than women independently of the age. However, that difference was because the group of men over 40 years had smaller diameter than women, which differs with Shigeta et al. and the majority of reports in other populations where women tend to have shorter NLD diameters. Most authors also report transverse and anteroposterior diameters greater than what we found (Groessl et al.; Janssen et al.; Shigeta et al.; McCormick \& Sloan) (Table III). This may be due to differences between Japanese, Hindu, Asian, African, and Mexican populations. The anteroposterior NLD diameter is greater than the transverse diameter in most reports, which is consistent with our study (Table III).
The limitation of this study is that the area of the bone entrance of the NLD was not measured, only its diameters. Since the diameter of the NLD bone entrance is shorter in men and lower lacrimal duct obstruction is more frequent in women our results may suggests the diameter of bone entrance of the NLD in general population does not appear to be an influential factor in the pathogenesis of lower lacrimal duct obstruction in Mexican population. Another weakness of the study is that it was performed in the general population and not in patients with a diagnosis of lower lacrimal duct obstruction, and it is assumed that individuals with obstruction of the lacrimal duct have anatomical alterations that were not found in our study population. Another limitation is that it was performed in dry orbits, so we could not take into consideration the membranous or soft tissue portion of the lacrimal duct, which could also influence the pathogenesis of lower lacrimal duct obstruction, as mentioned before.

Comparative in vivo morphological studies in individuals with and without obstruction of the lacrimal duct are needed, such as those performed by Janssen et al. in 2001 who found lower lacrimal duct obstruction in cases with a smaller NLD diameter than controls without obstruction $(\mathrm{p}=$ 0.001) (Table III).

In our study, the NLD length was significantly shorter in women than in men in both age groups and did not change with age, which coincides with some autors (Post, 1969; Ramey et al.); Post studied bone specimens in population from the United States following the same method as in our study and he found that NLD length was shorter in women than in men and shorter in older persons regardless of gender, but he reported higher length values. Ramey et al., using modified computed tomography, reported in that the NLD length similar to those obtained in our study. It is difficult to explain how the shorter NLD length can predispose to obstruction.

The width of the lower third of the LF in our study was similar between genders and smaller in women older than 40 years. Groell et al. (1997) in a study using CT scans in patients whose ethnic origin was not specified, obtained smaller results in the width of the fossa for lacrimal gland compared to the present study; however, in that study the portion in which the measures were made could explain the differences since in our study the dimensions of the FL varied according to the measured session.

The LF length was greater in women younger than 40 years of age than in men younger than 40 and in women older than 40 years. Yong et al. using CT reported values similar to our study with regard to the length of the LF (vertical diameter) in Southwestern Asian population. Fayet et al. (2005) and Groell et al. using CT reported shorter LF 
AGUILAR-MORALES, K.; AVALOS-FERNÁNDEZ, C. G.; MORALES-AVALOS, R.; MOHAMED-NORIEGA, K.; SÁNCHEZ-MEJORADA, G; MARTÍNEZ-FERNÁNDEZ, D. A.; MOHAMEDNORIEGA, J.; LUGO-GUILLEN, R. A.; VILLANUEVA-OLIVO, A.; CUERVO-LOZANO, E. E.; MOHAMED-HAMSHO, J.; ELIZONDO-OMAÑA, R. E. \& GUZMÁN-LÓPEZ, S. Sex and age morphometric variations in bony nasolacrimal duct and fossa for lacrimal gland in Mexican population. Int. J. Morphol., 36(2):635-641, 2018.

Table III. Results of transverse and anteroposterior diameters of nasolacrimal duct (NLD) in some studies (mean \pm SD).

\begin{tabular}{|c|c|c|c|c|}
\hline Study / Year / Population & $\mathrm{N}$ & $\begin{array}{l}\text { Method of } \\
\text { measurement }\end{array}$ & Transverse diameter & Anteroposterior diameter \\
\hline Takahashi et al. (2011), Japanise. ${ }^{7}$ & $\begin{array}{l}57 \text { cadaver orbits } \\
(37 \mathrm{M} \text { y } 20 \mathrm{~F})\end{array}$ & $\begin{array}{c}\text { bone } \\
\text { specimens }\end{array}$ & $\begin{array}{l}6.10 \mathrm{~mm} \text { (range: } 4.0-10.0 \\
\mathrm{~mm}) \mathrm{M} 5.00 \mathrm{~mm} \text { (range:4.0 } \\
-7.5 \mathrm{~mm}), \mathrm{F}(p=0.004)\end{array}$ & $\begin{array}{l}6.80 \text { (range: } 4.0-9.5 \mathrm{~mm}) \mathrm{M} \\
7.20 \mathrm{~mm}(\text { range }: 4.0-9.5 \mathrm{~mm}) \\
\mathrm{F}(p=0.287)\end{array}$ \\
\hline Takahashi et al. (2013), Japanese. ${ }^{8}$ & $\begin{array}{c}58 \mathrm{NLD} \\
(24 \mathrm{M} \text { y } 34 \mathrm{~F})\end{array}$ & $\begin{array}{l}\text { bone } \\
\text { specimens }\end{array}$ & $\begin{array}{l}7.30 \mathrm{~mm} \pm 1.30 \mathrm{M} \\
5.70 \mathrm{~mm} \pm 0.60 \mathrm{~F} \\
(p=0.019)\end{array}$ & $\begin{array}{l}5.70 \mathrm{~mm} \pm 0.90 \mathrm{M} \\
6.00 \mathrm{~mm} \pm 1.40 \mathrm{~F} \\
(p=0.456)\end{array}$ \\
\hline Saxena (1984), Hindu. ${ }^{10}$ & 400 cadaver orbits & $\begin{array}{c}\text { bone } \\
\text { specimens }\end{array}$ & $\begin{array}{l}4.10 \mathrm{~mm} \pm 0.09 \text { (right side) } \\
3.94 \mathrm{~mm} \pm 0.07 \text { (left side) } \\
(p=<0.05)\end{array}$ & $\begin{array}{l}4.26 \mathrm{~mm} \pm 0.08 \text { (right side) } \\
4.34 \mathrm{~mm} \pm 0.08 \text { (left side) } \\
(p=>0.05)\end{array}$ \\
\hline $\begin{array}{l}\text { Avalos-Fernández et al. (2015), } \\
\text { Mexicans (Present Study) (Tables I } \\
\text { and II) }\end{array}$ & $\begin{array}{l}114 \text { cadaver orbits } \\
(56 \mathrm{M} \text { y } 58 \mathrm{~F})\end{array}$ & $\begin{array}{l}\text { bone } \\
\text { specimens }\end{array}$ & $\begin{array}{l}2.72 \mathrm{~mm} \pm 0.56 \mathrm{M} \\
2.97 \mathrm{~mm} \pm 0.74 \mathrm{~F} \\
(p=0.045)\end{array}$ & $\begin{array}{l}3.55 \mathrm{~mm} \pm 0.74 \mathrm{M} \\
3.71 \mathrm{~mm} \pm 0.84 \mathrm{~F} \\
(p=0.289)\end{array}$ \\
\hline & & & $\begin{array}{l}2.89 \pm 0.54(\mathrm{M}<40) \\
3.03 \pm 0.58(\mathrm{~F}<40)(p=0.34) \\
2.50 \pm 0.49(\mathrm{M}>40) \\
2.92 \pm 0.85(\mathrm{~F}>40) \\
(p=0.04)\end{array}$ & $\begin{array}{l}3.36 \pm 0.58(\mathrm{M}<40) \\
3.65 \pm 0.85(\mathrm{~F}<40) \\
(p=0.13) \\
3.80 \pm 0.87(\mathrm{M}>40) \\
3.72 \pm 0.86(\mathrm{~F}>40) \\
(p=0.74)\end{array}$ \\
\hline Shigeta el al. (2007), Japanise. ${ }^{6}$ & $\begin{array}{c}314 \mathrm{TC} \\
(202 \mathrm{H} \text { y } 112 \mathrm{M})\end{array}$ & $\mathrm{CT}$ & $\begin{array}{l}5.10 \mathrm{~mm} \pm 1.10 \mathrm{M} \\
4.80 \mathrm{~mm} \pm 1.10 \mathrm{~F} \\
(p=0.005)\end{array}$ & $\begin{array}{l}5.80 \mathrm{~mm} \pm 1.20 \mathrm{M} \\
5.3 \mathrm{~mm} \pm 1.20 \mathrm{~F} \\
(p<0.001)\end{array}$ \\
\hline $\begin{array}{l}\text { Janssen et al. (2001), Healthy controls } \\
\text { and Patients with CNL obstruction, } \\
\text { No specific population. }\end{array}$ & $\begin{array}{c}200 \text { NLD control } \\
\text { group (100 M y } 100 \\
\text { F) } \\
24 \text { NLD patients } \\
\text { group (4 M y } 15 \mathrm{~F})\end{array}$ & $\mathrm{CT}$ & \multicolumn{2}{|c|}{$\begin{array}{l}\text { Minimum diameter of the NLD * } \\
3.70 \mathrm{~mm}(2.00-6.30) \mathrm{H} \text { (Control group) } \\
3.40 \mathrm{~mm}(1.50-5.40) \mathrm{M} \text { (Control group) } \\
3.00 \mathrm{~mm}(2.00-4.20) \text { Patients group } \\
\text { (without sex dis tinction) } \\
\text { M vs. F ( } p=0.022) \\
\text { Control vs. Patients }(p=0.001)\end{array}$} \\
\hline $\begin{array}{l}\text { McCormick \& Sloan (2009), Multiple } \\
\text { populations. }\end{array}$ & $\begin{array}{c}178 \mathrm{CT} \\
(87 \mathrm{M} \mathrm{y} 91 \mathrm{~F})\end{array}$ & $\mathrm{CT}$ & \multicolumn{2}{|c|}{$\begin{array}{l}\text { Minimum diameter of the NLD * } \\
3.90 \mathrm{~mm}(3.80-4.10) \mathrm{M} \\
3.60 \mathrm{~mm}(3.50-3.80) \mathrm{F} \\
\mathrm{M} \text { vs. F }(p=0.01)\end{array}$} \\
\hline Fasin a \& Ogbole (2013), Africans. ${ }^{11}$ & $\begin{array}{c}401 \mathrm{CT} \\
(286 \mathrm{M} \mathrm{y} 115 \mathrm{~F})\end{array}$ & $\mathrm{CT}$ & \multicolumn{2}{|c|}{$\begin{array}{l}\text { Minimum diameter of the NLD * } \\
3.33 \mathrm{~mm} \pm 0.69 \mathrm{M} \\
3.36 \mathrm{~mm} \pm 0.64 \mathrm{~F} \\
\text { M vs. F }(p=0.026)\end{array}$} \\
\hline $\begin{array}{l}\text { Yong et al. (2014), Southwest Asia } \\
\text { (Group 1) and South Asia and } \\
\text { Caucasians (Group 2)..2 }\end{array}$ & $\begin{array}{l}90 \mathrm{CT} \\
\text { (65 Group 1 y } 25 \\
\text { Group 2) }\end{array}$ & CT & \multicolumn{2}{|l|}{$\begin{array}{l}3.54 \mathrm{~mm} \pm 1.02 \text { Group } 2 \\
\text { Group } 1 \text { vs. Group } 2 \\
\text { OS }(p=0.889) \\
\text { OD }(p=0.254)\end{array}$} \\
\hline $\begin{array}{l}\text { Ramey et al. (2013), Multiple } \\
\text { populations. }{ }^{13}\end{array}$ & $\begin{array}{c}72 \mathrm{TC} \\
(36 \mathrm{M} \mathrm{y} 36 \mathrm{~F})\end{array}$ & $\mathrm{CT}$ & \multicolumn{2}{|c|}{$\begin{array}{l}3.63 \mathrm{~mm} \pm 0.70 \mathrm{M} \quad 3.62 \mathrm{~mm} \pm 0.90 \mathrm{~F} \\
\mathrm{M} \text { vs } \mathrm{F}(p=0.94) \\
3.40 \mathrm{~mm} \pm 0.80(<50 \text { years }) 3.80 \mathrm{~mm} \pm 0.90(>50 \text { years }) \\
(p=0.10)\end{array}$} \\
\hline
\end{tabular}

length measures than ours, but did not specify the population studied. The difference observed in the measurements reported by some authors may be due, among other things, to differences in the method of measurement and morphological differences among the ethnicities of the studied groups.

\section{CONCLUSIONS}

In our study on the lower lacrimal pathway in adults, we found significant differences between gender and age groups in some of the morphometric measurements.
Nasolacrimal duct in women had shorter length and wider duct entrance, Women <40 years had longer fossa for lacrimal gland a wider lower third fossa for lacrimal gland. Comparative studies between cases with and without obstruction of the lacrimal duct are needed to determine if the morphometric differences found in our study have a role in the etiology and sex differences in frequency of lower lacrimal pathway obstruction.

ACKNOWLEDGEMENTS. No type of external financing was provided. The Human Anatomy Department of the Universidad Autónoma de Nuevo León provided resources. 
AGUILAR-MORALES, K.; AVALOS-FERNÁNDEZ, C. G.; MORALES-AVALOS, R.; MOHAMED-NORIEGA, K.; SÁNCHEZ-MEJORADA, G; MARTÍNEZ-FERNÁNDEZ, D. A.; MOHAMEDNORIEGA, J.; LUGO-GUILLEN, R. A.; VILLANUEVA-OLIVO, A.; CUERVO-LOZANO, E. E.; MOHAMED-HAMSHO, J.; ELIZONDO-OMAÑA, R. E. \& GUZMÁN-LÓPEZ, S. Sex and age morphometric variations in bony nasolacrimal duct and fossa for lacrimal gland in Mexican population. Int. J. Morphol., 36(2):635-641, 2018.

We thank Guillermo Torres, physical anthropologist, for technical assistance provided for the study and Jaime Alberto Cisneros Ríos for his help in the creation and edition of the graphic material presented in this article. We also thank Sergio Lozano-Rodriguez, M.D. for his help in translating the manuscript.

AGUILAR-MORALES, K.; AVALOS-FERNÁNDEZ, C. G.; MORALES-AVALOS, R.; MOHAMED-NORIEGA, K.; SÁNCHEZ-MEJORADA, G; MARTÍNEZ-FERNÁNDEZ, D. A.; MOHAMED-NORIEGA, J.; LUGO-GUILLEN, R. A.; VILLANUEVA-OLIVO, A.; CUERVO-LOZANO, E. E.; MOHAMED-HAMSHO, J.; ELIZONDO-OMAÑA, R. E. \& GUZMÁN-LÓPEZ, S. Variaciones morfométricas de sexo y edad en el conducto nasolagrimal óseo y la fosa de la glándula lagrimal en la población mexicana. Int. J. Morphol., 36(2):635-641, 2018.

RESUMEN: La obstrucción de la vía lagrimal inferior es mayor en mujeres mayores de 50 años y se ha asociado a variaciones morfométricas en la entrada ósea del conducto nasolagrimal (CNL), las cuales varían según edad y sexo. El objetivo del presente estudio es determinar las variaciones respecto a sexo y edad de los diámetros de la entrada ósea del CNL, longitud del CNL y fosa de la glángula lagrimal (FL) ósea. Se analizaron 116 órbitas secas de población mexicana, los cuales a su vez fueron subdivididos en dos subgrupos en base a la edad y sexo. Se determinaron los diámetros transverso y anteroposterior de la entrada ósea del CNL, la longitud del CNL y la longitud y anchura de la FL. Se aplicaron pruebas estadísticas para determinar la significancia de las diferencias entre los grupos de estudio. La longitud del CNL fue menor en mujeres que en hombres en ambos grupos de edad. En cuanto a la entrada ósea del CNL, el diámetro transverso de fue significativamente menor en hombres que en mujeres independientemente de la edad y el diámetro anteroposterior fue menor en hombres $<40$ que en $>40$. La longitud de la FL fue mayor en mujeres $<40$ años que en hombres del mismo rango de edad y que en mujeres $>40$ años. La anchura de la FL en el tercio inferior fue menor en mujeres $>40$ años que $<40$ años. el resto de las mediciones de la FL no presentó diferencias significativas por sexo ni grupo de edad. Nuestro estudio confirmó que existen diferencias entre sexo y grupo de edad en algunas mediciones morfométricas del CNL y FL óseas en población mexicana. Se necesitan estudios comparativos entre personas con y sin obstrucción clínica de vía lagrimal inferior para esclarecer si las características óseas de estas estructuras participan o no en la etiopatogenia y las diferencias de distribución en género, edad y etnia de esta enfermedad.

PALABRAS CLAVE: Conducto nasolagrimal; Anatomía; Morfometría; Fosa lagrimal; Sexo; Edad; Obstrucción de vía lagrimal.

\section{REFERENCES}

Bartley, G. B. Acquired lacrimal drainage obstruction: an etiologic classification system, case reports, and a review of the literature. Part 1. Ophthal. Plast. Reconstr. Surg., 8(4):237-42, 1992.

Fasina, O. \& Ogbole, G. I. CT assessment of the nasolacrimal canal in a black
African population. Ophthal. Plast. Reconstr. Surg., 29(3):231-3, 2013.

Fayet, B.; Racy, E.; Assouline, M. \& Zerbib, M. Surgical anatomy of the lacrimal fossa a prospective computed tomodensitometry scan analysis. Ophthalmology, 112(6):1119-28, 2005.

Francisco, F. C.; Carvalho, A. C.; Francisco, V. F.; Francisco, M. C. \& Neto, G. T. Evaluation of 1000 lacrimal ducts by dacryocystography. $\mathrm{Br} . \mathrm{J}$. Ophthalmol., 91(1):43-6, 2007.

Groell, R.; Schaffler, G. J.; Uggowitzer, M.; Szolar, D. H. \& Muellner, K. CTanatomy of the nasolacrimal sac and duct. Surg. Radiol. Anat., 19(3):18991, 1997.

Groessl, S. A.; Sires, B. S. \& Lemke, B. N. An anatomical basis for primary acquired nasolacrimal duct obstruction. Arch. Ophthalmol., 115(1):71-4, 1997.

Janssen, A. G.; Mansour, K.; Bos, J. J. \& Castelijns, J. A. Diameter of the bony lacrimal canal: normal values and values related to nasolacrimal duct obstruction: assessment with CT. A. J. N. R. Am. J. Neuroradiol., 22(5):845-50, 2001.

McCormick, A. \& Sloan, B. The diameter of the nasolacrimal canal measured by computed tomography: gender and racial differences. Clin. Exp. Ophthalmol., 37(4):357-61, 2009.

Post, R. H. Tear duct size differences of age, sex and race. Am. J. Phys. Anthropol., 30(1):85-8, 1969.

Ramey, N. A.; Hoang, J. K. \& Richard, M. J. Multidetector CT of nasolacrimal canal morphology: normal variation by age, gender, and race. Ophthal. Plast. Reconstr. Surg., 29(6):475-80, 2013.

Sasaki, T.; Nagata, Y. \& Sugiyama, K. Nasolacrimal duct obstruction classified by dacryoendoscopy and treated with inferior meatal dacryorhinotomy. Part I: Positional diagnosis of primary nasolacrimal duct obstruction with dacryoendoscope. Am. J. Ophthalmol., 140(6):1065-9, 2005.

Saxena, S. K. A study of nasolacrimal canal in crania from Uttar Pradesh (India). Anthropol. Anz., 42(4):265-9, 1984.

Shigeta, K.; Takegoshi, H. \& Kikuchi, S. Sex and age differences in the bony nasolacrimal canal: an anatomical study. Arch. Ophthalmol., 125(12):167781, 2007.

Takahashi, Y.; Kakizaki, H. \& Nakano, T. Bony nasolacrimal duct entrance diameter: gender difference in cadaveric study. Ophthal. Plast. Reconstr. Surg., 27(3):204-5, 2011.

Takahashi, Y.; Nakamura, Y.; Nakano, T.; Asamoto, K.; Iwaki, M.; Selva, D.; Leibovitch, I. \& Kakizaki, H. The narrowest part of the bony nasolacrimal canal: an anatomical study. Ophthal. Plast. Reconstr. Surg., 29(4):31822, 2013.

Welham, R. A. \& Wulc, A. E. Management of unsuccessful lacrimal surgery. Br. J. Ophthalmol., 71(2):152-7, 1987.

Woog, J. J. The incidence of symptomatic acquired lacrimal outflow obstruction among residents of Olmsted County, Minnesota, 1976-2000 (an American Ophthalmological Society thesis). Trans. Am. Ophthalmol. Soc., 105:64966, 2007.

Yong, A. M.; Zhao, D. B.; Siew, S. C.; Goh, P. S.; Liao, J. \& Amrith, S. Assessment of bony nasolacrimal parameters among Asians. Ophthal. Plast. Reconstr. Surg., 30(4):322-7, 2014.

\section{Corresponding author:}

Rodrigo E. Elizondo-Omaña, Dr. Sc.

Departamento de Anatomía Humana

Facultad de Medicina y Hospital Universitario "Dr. José

Eleuterio González"

Universidad Autónoma de Nuevo León

Ave. Madero s/n Colonia Mitras Centro

Monterrey, Nuevo León

MÉXICO

E-mail: rod_omana@yahoo.com

Received: 02-10-2017

Accepted: 23-10-2017 